\title{
The Watt Bicentenary Celebrations
}

$\mathrm{T}$

HE bicentenary of the birth of James Watt is being commemorated in many ways and in many places, and on a scale worthy of a great international figure. "Science," Lord Playfair once said, "has no country though its investigators have birthplaces"; and the commemorations of Watt in places so far apart as America and Japan show that he is recognised as a world benefactor. In recent years, numerous centenary tributes have been paid to inventors and engineers such as Maudslay, Symington, Bell, Matthew Murray, Crompton, Trevithick and Telford-to mention only those of British birth-but the earliest and most notable of such recognitions in the present century was that at Birmingham in 1919, on the occasion of the centenary of Watt's death. The Birmingham gatherings had very valuable results. They led to the founding of a James Watt fellowship in the University, the writing of the monumental work of Mr. Rhys Jenkins and Mr. H. W. Dickinson on "James Watt and the Steam Engine", and they also led to the founding of the Newcomen Society for the Study of the History of Engineering and Technology which has, among other things, helped to stimulate, both at home and abroad, an interest in the lives and achievements of the pioneers of the past.

While it was appropriate that the centenary commemoration of the death of Watt should be held in Birmingham, where with Matthew Boulton as his constant guide and philosopher, Watt did the principal work of his life, it is natural that in the present celebrations of the bicentenary of his birth, Greenock, where he was born on January 19, 1736, should take the leading part. On Monday, January 13, therefore, Greenock began a week's celebrations with the opening of an exhibition in the Watt Institution, which was very largely the gift of James Watt, jun. Watt himself was a generous contributor to the library there, for in 1816 he gave $£ 100$ for the purchase of books for the youth of Greenock. The foundation stone of the Institution was laid just a century ago by Sir Michael Shaw-Stewart, Bt., the grandfather of Sir Hugh Shaw-Stewart, who on Monday opened the exhibition, and in doing so recalled the words used by his grandfather in 1836 : "We narrow the reputation of Mr. Watt if we consider him only as a great practical mechanic; I believe him to be a profound philosopher and subtle chemist".

The opening of the exhibition was followed on
Wednesday and Thursday by a pageant in the Greenock Town Hall by pupils of the High School, and on Friday, January 17, Lord Rutherford delivered the Watt Anniversary Lecture to the Greenock Philosophical Society, taking for his subject "The Transformation of Energy". Previous Watt lecturers have included Parsons, Ramsay, Preece, Bramwell, Balfour Stewart, Tait, Maxwel] and Kelvin, the first of all being Joule, who in 1865 took as the title for his lecture, "On some facts in the Science of Heat developed since the time of Watt". The conservation of energy, radioactive energy, radiation and matter, and matter and energy are all included in the list of Watt lectures of the past, while so recently as 1930, Prof. C. G. Darwin spoke on "The New Conceptions of Matter". Lord Rutherford's lecture therefore may be considered as the latest in a valuable series of closely related discourses spread over the last seventy years.

In the opening passages of his lecture, Lord Rutherford spoke at some length of the association of Watt with Black, and the influence this had on the work of Watt on the Newcomen steam engine and the invention of the separate condenser; he then turned to review the work of Rumford, Mayer, Joule, Helmholtz, Carnot, Clausius and Kelvin, the enunciation of the laws of thermodynamies, the development of the principle of the conservation of energy and the possible efficiency of heat engines, touching also upon the use of highpressure steam and the development of the mercury boiler and turbine due to Emmet in America. In speaking of the conservation of energy, Lord Rutherford said : "It must be borne in mind that 'energy', which is generally defined as 'the capacity for doing work', is an abstract conception, for energy can neither be seen nor measured directly. Its evaluation depends on the measurement of other quantities, and these are different for each type of energy involved. While it is an act of faith to believe that the conservation of energy does apply to all physical systems, yet we know it is difficult in many cases to obtain a direct experimental proof of its validity. Each case of transformation has to be examined with great care to be sure that energy has not disappeared in some unrecognised form." Lord Rutherford then went on to deal with the further important extensions to our ideas of energy and its transformations which belong to the present century, and exert to-day a profound 
influence on the progress of atomic physics. This portion of his address is printed elsewhere in this issue.

The committee which arranged the Greenock celebrations, of which Mr. H. Ferrier is the chairman and Mr. H. Henderson the honorary secretary, appealed for funds for three objects. One of these was to found a prize fund for engineering students, another to complete the Watt Cairn in the Greenock Cemetery, and the third to place a plaque in the vestibule of the Watt Memorial Engineering and Navigation School which stands on the site of Watt's birthplace. The Cairn dates from 1854 and consists of stones brought from different parts of the world to form an international memorial. These stones at present are in an irregular heap, and it is now proposed to build them into a simple finished design. The plaque, however, has been erected, and at noon on Saturday, January 18, was unveiled by Sir Godfrey Collins, M.P. for Greenock and Secretary of State for Scotland. The inauguration of this memorial was followed on Sunday, January 19-the actual anniversary of Watt's birth-by a commemoration service in Greenock Town Hall, the address being given by Dr. C. L. Ward, Dean of the Thistle and Chapel Royal. The service was broadeast by the British Broadcasting Corporation from its Scottish station.

As already mentioned in our columns, a Watt Bicentenary Exhibition has been arranged in the Science Museum and will be on view until April 19. The Museum already possesses a valuable and varied collection of documents, apparatus, models and engines illustrating Watt's work, and also his garret workshop with all its contents. This was given to the Museum in 1924 shortly before his house, Heathfield Hall, Handsworth, was pulled down. A catalogue of the exhibition has been prepared by Mr. A. Stowers, and it includes many notes on objects lent for the occasion by various institutions and individuals.

On Friday, January 17, the members of the Institution of Mechanical Engineers made an official visit to the Science Museum to inspect the Watt exhibits and to hear a lecture on the life and work of Watt by Sir Thomas Hudson Beare. The lecture was given in the Lecture Theatre and was listened to by a large audience. Though Sir Hudson confined himself closely to his subject and attempted no review of the effect of the work of Watt and his fellows on the progress of the Industrial Revolution, he brought out clearly the influence of his surroundings on Watt, his standing among his scientific contemporaries and his originality of mind. The president of the Institution, Colonel A. E. Davidson, was in the chair, and at the close of the proceedings said that a bequest had been made to the Institution, and it had been decided with it to found a Watt Medal.

The London celebrations were continued on Sunday, January 19, when many representatives of the Institution of Civil Engineers, the Institution of Mechanical Engineers, the Institution of Naval Architects, the Newcomen Society and other bodies attended evensong in Westminster Abbey. The service was conducted by the Rev. Canon F. R. Barry, while the preacher was the Bishop of Knaresborough, Dr. P. F. D. de Labilliere. The sermon, which was based on the text Matthew, xvi, 26, is printed on other pages of this issue. At the close of the service, a small procession pro. ceeded to St. Paul's Chapel, where three wreaths were placed upon the Watt monument; one of these was from the Institution of Mechanical Engineers, another from the Institution of Naval Architects, while that placed in position by the president of the Institution of Civil Engineers was deposited on behalf of all the other institutions represented at the service. This monument to Watt bears Brougham's famous inscription beginning: "Not to perpetuate a name which must endure while the peaceful arts flourish, but to show that mankind has learnt to honour those who best deserve their gratitude . ..", an inscription of which Dean Stanley said that "in its vigorous style and scientific enthusiasm, it is not unworthy of the omnigenous knowledge of him who wrote it, or of the powerful intellect and vast discovery which it is intended to describe". Finally, a few of those present were conducted by the Dean of Westminster, the Very Rev. W. Foxley Norris, to the Vestry, where they signed the Preachers' Register.

It was shortly after the conclusion of this service that Colonel A. E. Davidson and Mr. H. W. Dickinson, by the permission of the Director of the Science Museum and arrangements made by the Columbia Broadcasting Corporation, gave short addresses at the Museum which were broadcast in America, where the celebrations arranged by the Lehigh University, the Franklin Institute, the American Society of Mechanical Engineers and the American Section of the Newcomen Society were just being inaugurated in the Franklin Institute. The proceedings in America extended over Sunday, Monday and Tuesday, and were of a notable character.

On Monday, January 20, at 8.30 , the British Broadcasting Corporation included in its National programme an item entitled "The Romance of Steam Power" and on the following Wednesday, the Newcomen Society held a meeting in the Science Museum to receive a series of short papers. One of these was by Prof. P. Labarinsky, of the 
Academy of Sciences of the U.S.S.R., Leningrad, its subject being the "Earliest News of Watt's Steam Engine to Reach Russia". Another paper by Mr. Rhys Jenkins was entitled "The Note Book of Roger North and the Work of Sir. S. Morland in the Steam Engine". Roger North (1653-1734), a lawyer, was the brother of Francis North, Lord Guildford. In the British Museum is a note-book of his containing some leaves devoted to mechanical subjects. Some of the sketches were of what Mr. Jenkins referred to as "a two-cylinder, single-acting, high-pressure condensing engine with automatic valve gear". Was it an engine of Savery's, Newcomen's, Papin's or Morland's?
Morland in 1673 asked for a patent for "An engine capable of raising water to any height by the help of steam", and in 1682 showed an engine to the King. But in the seventeenth century many men were at work on the steam engine. Some were concerned with the philosophical aspect of the subject, others had in view applications in practice. It is quite possible, indeed likely, that there were other workers in the field of whom we have no knowledge. In historical research from time to time buried material comes to light, necessitating a revision of our conclusions, and it may yet be possible to discover the inventor of the engine as described by Roger North.

\title{
Watt Commemoration in Westminster Abbey
}

\author{
Sermon by the Right Rev. P. F. D. De Labilliere, Bishop of Knaresborough
}

What is a man profited, if he shall gain the whole world, and lose his own soul ?

S. Matt. xvi. 26.

$\mathrm{W}^{\mathrm{B}}$ E are celebrating to-day (January 19) the two hundredth anniversary of the birth of James Watt- "the improver of the steam engine" -whose gigantic statue yonder in the Chapel of St. Paul, with its inscription from the pen of Lord Brougham, testifies to the high honour in which he was held by the men of his generation.

The basic principles of the steam-engine, it would appear, were already known when Watt embarked upon his investigations--but its use had. been confined almost entirely to providing a satisfactory method of draining water from the newlyopened coal-mines-"a giant with one idea" as Coleridge called it. It was James Watt who improved this steam pumping engine and made it available for driving other types of machinery, so that when he died in 1819, the "giant with one idea" was capable of being used for an almost infinite variety of purposes.

Thanks to Watt's inventive genius, man had successfully harnessed the power of steam to his triumphal chariot, and the stage was set for the inauguration of the Mechanical Age, which made Britain for nearly a century the workshop of the world.

Speaking of the erection of James Watt's monument in the Abbey, Dean Stanley writes:

"Well may the ancient pavement of the Church have cracked and yawned, as the enormous monster moved into its place, and disclosed to the eyes of the astonished workmen, rows upon rows of gilded coffins in the vaults beneath. . . . Well might the standard-bearer of Agincourt, and the worthies of the courts of Elizabeth and James, have started from their tombs in S. Paul's Chapel, if they could have seen this colossal champion of a new plebeian art enter their aristocratic restingplace. . . .

"Yet when we consider what this vast figure represents, what class of interests before unknown, what revolutions in the whole actual framework of society, equal to any that the Abbey walls have yet commemorated, there is surely a fitness even in its very incongruity."

We may truly, then, regard James Watt as one of the foremost pioneers of the Machine Age, and on this bicentenary of his birth concentrate our thoughts upon some of the ways in which mechanical invention has affected human life and thought.

Think for a moment of the extent to which the man of to-day lives his ordinary life under the domination of the machine. In our homes we rely upon electric light, vacuum cleaners, sewingmachines and consider them only half-furnished unless we have also a telephone, a wireless set and perhaps a gramophone as well. Small wonder that an eminent modern architect (de Courbousier) has defined a house as "a machine for living in". Our offices are equipped with typewriters, calculatingmachines and cash-registers, if not with dictaphones.

We go out into our streets and count on being able to use electric trams or motor buses or 